\title{
Penerapan Teknologi Website dan Email Dalam Proses Pembelajaran
}

Muhammad Ullil Fahri

muhammad.fahri001@binus.ac.id

\section{Pemanfaatan Website dalam Proses Pembelajaran}

Manfaat website bagi pembelajaran selanjutnya adalah sebagai sumber belajar. Mungkin dulu sumber belajar atau pembelajaran adalah buku. Akan tetapi, dengan adanya website sekarang ini kita bisa menambah sumber pembelajaran. Bahkan, dengan adanya website kita bisa belajar dari semua sumber yang ada. Tentunya dengan belajar dari berbagai sumber yang ada, akan menambah wawasan dalam pembelajaran [1]. Dengan adanya website dapat membantu siswa belajar secara mandiri tentunya. Sumber belajar yang awalnya hanya dari guru sekarang bisa didapatkan oleh siswa dari sarana website. Dengan menggunakan mesin pencari seperti google siswa dapat dengan mudah menambah pengetahuan mereka secara mandiri. Tentunya jika ada yang tidak dimengerti oleh guru, disinilah peran guru menjelaskan yang bagian tidak mengerti oleh siswa. Siswa mendapatkan sumber yang banyak yang kemudian bisa didiskusikan bersama guru. Yang jadi masalah sekarang adalah tinggal tergantung dari kesiapan guru apakah bisa menerima proses pembelajaran dari sumber yang lain.

pengaruh yang sedang dan kontribusi rendah pemanfaatan media pembelajaran berbasis website terhadap hasil belajar kognitif siswa [2]. dari penelitian diatas dengan menggunakan website dapat membantu hasil belajar siswa terutama di ranah kognitif. Hasil belajar kognitif adalah kemampuan siswa dalam mempelajari suatu konsep di sekolah dan dinyatakan dalam skor melalui hasil tes (Susanto, 2013) untuk mengetahui tingkat keberhasilan dalam pencapaian pembelajaran [3]. Dalam hal ini melakukan kombinasi sumber belajar yang ada dari guru dengan mengkombinasikan sumber belajar dari internet yang ada di siswa. Siswa dapat pengetahuan secara luas yang tidak hanya didapatkan dari guru saja tetapi didapatkan dari hasil belajar secara mandiri. Dari pengalaman ini siswa dapat menjawab hasil tes berdasarkan pengetahuan tambahan yang di dapatkan.

Pada proses pembelajaran berbasis web yang berfungsi sebagai pengganti, siswa memanfaatkan web pembelajaran sebagai pengganti pembelajaran konvensional. Namun, pembelajaran tersebut tetap dalam bimbingan guru karena jika ada materi yang kurang dipahami oleh siswa, guru dapat menjelaskan secara langsung. Pembelajaran berbasis web akan memberikan inovasi dalam pembelajaran, sehingga menimbulkan ketertarikan dan motivasi belajar bagi siswa. Dari segi manfaat, bila pembelajaran berbasis web dirancang dengan baik dan tepat, maka dapat menjadikan pembelajaran yang menyenangkan, memiliki unsur interaktivitas yang tinggi, menyebabkan peserta didik mengingat lebih banyak materi ajar, serta mengurangi biaya-biaya operasional yang biasanya dikeluarkan oleh peserta didik untuk mengikuti pembelajaran [4]. walaupun sudah ada media website, tetap peran guru tidak bisa dihilangkan. Hal ini dikarenakan guru sebagai pemberi solusi ketika siswa belum paham dalam sumber belajar yang didapatkannya lewat website. Harapan dalam penggunaan media website adalah mampu memberikan motivasi siswa untuk belajar. Misalnya pada mata pelajaran praktek jaringan komputer, dengan media website dapat di tambahkan video cara merakit jaringan pada website. Hal ini tentunya dapat dengan mudah membantu siswa belajar secara mandiri dirumah. Guru tidak perlu lagi menjelaskan di sekolah cara merakit jaringan komputer menggunakan presentasi power point. Siswa bisa diminta mengikuti link yang diberikan sebagai bahan sumber video pembelajaran.

Seiring perkembangan zaman, selaras dengan perkembangan teknologi yang telah perkembang pesat, fasilitas pembelajaran yang efektif akan menunjang kualitas pembelajaran jarak jauh. Dengan menyiapkan sites website seperti google sites akan memudahkan proses pembelajaran dengan segala fitur-fitur yang ditawarkan sehingga guru dapat menyampaikan 
pesan pembelajaran secara efektif [5]. pembelajaran jarak jauh sekarang sudah dilakukan semenjak adanya pandemi covid. Guru mulai aktif dalam penggunaan sistem pembelajaran secara jarak jauh. Harapan adalah pembelajaran dalam dilakukan secara efektif. Namun sekarang pembelajar jarak jauh tentunya masih menyimpan banyak masalah dalam penerapan. Keunggulan google sites dapat menjadi sarana bagi guru dan siswa dalam sharing knowledge (berbagi pengetahuan) dan informasi dalam bentuk dokumentasi yang menarik. Google sites juga sebagai sarana bagi guru untuk mengkomunikasikan kepada orang tua siswa terkait berbagai progres pembelajaran atau dokumentasi siswa, orang tua dapat mengunjungi google sites siswa secara berkala agar mengetahui berbagai informasi pembelajaran anaknya, ini merupakan bentuk kerjasama guru dan orang tua dalam mencapai tujuan pembelajaran bersama [5]. Google sites bisa menjadi solusi untuk guru yang belum memiliki website secara pribadi. Dengan memanfaatkan google sites yang dapat diakses pada alamat https://sites.google.com/ guru dapat dengan mudah melakukan upload materi secara mandiri.

\section{Email Sebagai Komunikasi Pembelajaran}

Meski dinilai praktis dan cepat, namun sebenarnya keberadaan email mulai tergeser dengan munculnya berbagai aplikasi chatting yang lebih mudah dan real-time. Seperti aplikasi WhatsApp, Telegram, Messenger, Skype, dan sebagainya. Aplikasi-aplikasi tersebut sangatlah cocok untuk berkirim pesan secara cepat dan real-time. Meski begitu, ada beberapa ranah email yang tak bisa digantikan begitu saja dengan hadirnya berbagai macam aplikasi chat yang muncul di pasaran. Berikut adalah peran email yang tidak bisa tergantikan [6]:

1. Mengirim dan Menerima Pesan ( File Besar )

2. Akses Mudah untuk Mendaftar di Media Sosial

3. Sebagai Identitas Diri

4. Sebagai Media Pemasaran

5. Mengirimkan Pesan ke Grup

6.

Beda halnya dengan pesan install yang real time seperti whatsapp. Email sifatnya lebih formal dalam melakukan kirim pesan, beda halnya dengan aplikasi pesan media sosial sifatnya hanya sebagai chating biasa yang membuat kesan kurang formal. Terutama dalam bidang pekerjaan. Pada email lebih praktik dikarenakan kita sudah disiapkan template untuk mengirim pesan. Pesan yang disimpan gambar dan bisa didesain sesuai keinginan.

Banyak peserta didik (baik siswa maupun mahasiswa) yang menggunakan e-mail sebagai salah satu media atau perantara mengirimkan tugas kepada pendidik (guru atau dosennya) maupun antar peserta didik itu sendiri. Adapun kelebihan dengan menggunakan e-mail, yaitu [7]:

1. mudah, karena hanya menggunakan jaringan internet untuk mengirim datanya

2. cepat, tidak membutuhkan waktu yang lama

3. biaya pengiriman relatif murah, jika dibandingkan penggunaan telepon atau mengirim surat ke luar daerah maupun luar negeri

4. global, bisa digunakan oleh siapa saja, kapan saja, dan dimana saja sebagai sarana komunikasi seluruh dunia

5. reliabel, dapat menyimpan e-mail di server yang tidak akan hilang, kecuali di hapus

6. sebagai pesan multimedia, yang dapat mengirim data bukan hanya teks saja, tetapi dapat berupa gambar, audio, dan video.

Walaupun sekarang sudah mulai banyak media sosial yang lebih install dalam pengiriman pesan tetapi peran email masih belum bisa tergantikan. Dalam hal kirim file multimedia keunggulan email lebih hebat dibandingkan dengan pesan instan. kekurangan dari penggunaan e-mail, yaitu [7] :

1. salah kirim alamat email, jika data yang dikirim merupakan data rahasia bisa saja disalahgunakan

2. pemalsuan identitas, karena tidak bisa memastikan keaslian identitas hanya dari alamat e-mail saja

3. banyak sampah email, berupa iklan komersial

4. respon terlambat, tidak semua orang membaca e-mail setiap hari, sehingga ada kemungkinan balasan e-mail 
mengalami keterlambatan.

Banyak pelajar yang terbantu dengan adanya email. Berikut manfaat email bagi pelajar [8] :

1. Sarana bertukar informasi

2. Dapat mengerjakan tugas dimana saja karena tidak terikat dengan tempat

3. Akses dunia pendidikan yang semakin luas

4. Menghemat biaya karena tugas tidak perlu memerlukan kertas

5. Sarana pengiriman dokumen

6. Media pembelajaran yang efektif

7. Memperbanyak teman melalui situs jejaring sosial

dengan menggunakan email tentunya tidak hanya dirasakan di dunia kerja saja. Pelajar yang masih sekolah harus sudah mulai dibiasakan menggunakan email. Hal ini dikarenakan sudah mulai penggunaan email untuk dijadikan lamaran kerja. Cara penulisan email yang baik harus sudah diajarkan sejak dini, gunakan kalimat yth. Di setiap awal email. Penulisan email sifatnya adalah formal sehingga menulis email bisa dikatakan sama halnya kita dalam mengirim surat resmi ke suatu instansi.

Terdapat pengaruh pemberian tugas melalui email pada pembelajaran langsung terhadap hasil belajar [9] . dengan memberikan perintah ke siswa dengan mengirimkan tugas melalui email dapat mempengaruhi hasil belajar siswa. Tentunya siswa dapat dengan mudah mengirimkan tugas tanpa perlu lagi melakukan print dengan biaya yang mahal. Siswa dapat mengirim tugas dalam bentuk pdf yang tentunya dapat diterima oleh guru. 


\section{DAFTAR PUSTAKA}

[1] Lendcreative, “9 Manfaat Website Bagi Pembelajaran,” 2018. https://lendcreative.com/9manfaat-website-bagi-pembelajaran/\#: :text=Pada dasarnya manfaat website untuk,dan kapan saja kita mau. (accessed Oct. 27, 2020).

[2] E. T. B. Rahman, Syaiful Munawar, Wahid, "PEMANFAATAN MEDIA PEMBELAJARAN BERBASIS WEBSITE PADA PROSES PEMBELAJARAN PRODUKTIF DI SMK,” J. Mech. Eng. Educ., vol. 1, 2014.

[3] V. U. R. S. Lusia Naimnule, Vinsensius Oetpah, "PENINGKATAN AKTIVITAS DAN HASIL BELAJAR KOGNITIF SISWA MELALUI PENERAPAN MODEL PEMBELAJARAN THINK TALK WRITE (TTW) DI SMUK,” J. Pendidik., vol. 1, 2016.

[4] http://edel.staff.unja.ac.id/, "Fungsi dan Manfaat Pembelajaran Berbasis Web,” 2016. http://edel.staff.unja.ac.id/blog/artikel/Fungsi-dan-Manfaat-Pembelajaran-Berbasis-Web.html (accessed Oct. 27, 2020).

[5] Ferismayanti, "Mengoptimalkan Pemanfaatan Google Sites dalam Pembelajaran Jarak Jauh.”

[6] Hairo, “Manfaat Email,” 2020. https://www.selamatpagi.id/manfaat-email/amp/ (accessed Oct. 27, 2020).

[7] M. Puspita, "Pemanfaatan E-mail sebagai Media atau Perantara Pengiriman Tugas.” https://sites.google.com/site/elearningpp09/e-learning/pemanfaatan-email-sebagai-mediadan-perantara-pengirim-tugas (accessed Oct. 27, 2020).

[8] Otib, “7 Manfaat Email Bagi Pelajar Dalam Menunjang Proses Pembelajaran,” 2017. https://saatsantai.com/manfaat-email-bagi-pelajar/ (accessed Oct. 27, 2020).

[9] J. Ahmad, Laylah Fiamanillah, H. Muh. Yunus, "Pengaruh E-Mail pada Pemberian Tugas dengan Menggunakan Pembelajaran Langsung terhadap Hasil Belajar Siswa Kelas XI IPA SMA Negeri 1 Bajeng (Studi pada Sub. Materi Pokok Hidrolisis Garam),” J. Chem., vol. 15, 2014. 
